\title{
THE METHODS FOR SELECTION OF SHARES FOR INVESTMENT PORTFOLIO ON EXAMPLE OF COMPANIES IN THE STOCK EXCHANGE IN WARSAW
}

\author{
Monika MIŚKIEWICZ-NAWROCKA \\ University of Economics in Katowice; monika.miskiewicz@ue.katowice.pl, ORCID: 0000-0002-2766-1322
}

Purpose: The research on the composition of the optimal securities portfolio, conducted for many years, provides new tools and approaches not only to determining the shares of financial instruments in an optimal portfolio but also to the selection of instruments for the portfolio. One of the new approaches is the use of deterministic chaos to determine the composition of the portfolio. The purpose of the paper is to create company rankings and to assess the efficiency of investment portfolios built on their basis.

Design/methodology/approach: In order to rank companies in terms of investment attractiveness, and to build and evaluate the efficiency of investment portfolios created on the basis of the division made, the analysis used such measures as: beta coefficient, Hurst exponent, synthetic measures: TMAI and WAI.

Findings: The applied measures allowed to rank and divide listed companies due to the level of attractiveness for an investor. The research shows that better results were obtained for portfolios built on the basis of synthetic measures i.e. TMAI than WAI.

Research limitations/implications: An important element of portfolio analysis research seems to be the use of tools such as the Hurst exponent. The research showed that the selection of shares for the portfolio based on the Hurst exponent often gives better or as good results as the methods taking into account the economic and financial situation of a company.

Practical implications: The application in portfolio analysis.

Originality/value: The WAI measures used to create a company ranking and build a portfolio of shares based on it. The application tools of deterministic chaos to determine the composition of the portfolio.

Keywords: beta coefficient, TMAI measure, WAI measure, Hurst exponent, investment portfolio.

Category of the paper: Research paper. 


\section{Introduction}

The expected rate of return and risk of the investment portfolio are the basic parameters used to assess its attractiveness by investors. In recent years, there have appeared many methods to make the right choice of financial instruments for the portfolio. They include methods and tools for technical analysis, fundamental analysis or derived from the theory of non-linear dynamic systems (chaos theory).

The aim of the article is to rank companies in terms of investment attractiveness, and to build and evaluate the efficiency of investment portfolios created on the basis of the division made. The analysis used such measures as: beta coefficient, Hurst exponent, synthetic measures: TMAI and WAI. The actual data from the Stock Exchange in Warsaw were used for the study.

\section{The beta coefficient}

The beta coefficient is a measure of risk arising from exposure to general market movements. The beta is estimated based on the regression equation presenting the dependence of the rate of return on shares on the return rate of the stock market index (market portfolio) (Jajuga, Jajuga, 2000):

$$
R_{i}=\alpha_{i}+\beta_{i} R_{M}+e_{i}
$$

where:

$R_{i}$ - the return rate of $i$-th share,

$R_{M}$ - the return rate of the stock market index,

$\alpha_{i}, \beta_{i}$ - the equation coefficients,

$e_{i}$ - the random factor.

The beta ratio of shares shows by how many percent will the rate of return of the stock approximately increase when the rate of return of the market index increases by $1 \%$. The beta can accept any real values. $\beta=1$ means that the rate of return of shares changes at the same rate as the rate of return of the stock index. For $\beta=0$. the rate of return of shares does not react to changes in the stock index. Such a share is free from market risk. If $\beta>1$, the rate of return of shares largely reacts to changes on the market (aggressive share). If $0<\beta<1$, the rate of return of the shares responds to changes on the market to a small extent (defensive share). $\beta<0$ means that the rate of return of the shares reacts to the changes opposite to the market (Jajuga, Jajuga, 2000). 


\section{The TMAI measure}

The taxonomic measure of investment attractiveness (TMAI) is one of the methods for the selection of companies (Tarczyński, 2002; Tarczyński, 1999). This method allows for a comprehensive evaluation of the companies based on key financial and market indicators and presenting them in the form of synthetic measure.

Building the taxonomic measure consists of three stages (Tarczyński, 2004; 2013). First, we create 2-dimensional data matrix containing observations $x_{i j}$ of the diagnostic features of selected objects. We normalize (standardize) these values, following the formula:

$$
y_{i j}=\left(x_{i j}-\bar{x}_{j}\right) / S_{j}, \quad i=1, \ldots, n ; \quad j=1, \ldots, m,
$$

where:

$x_{i j}$ - value of $j$-th diagnostic features for $i$-th object,

$\bar{x}_{j}$ - mean of feature $j$,

$S_{j}$ - standard deviation for $j$.

We estimate the TMAI measure using the formula:

$$
\operatorname{TMAI}_{i}=1-\frac{d_{i}}{d_{0}}, \quad i=1, \ldots, n,
$$

where:

$d_{i}=\left[\frac{1}{m} \sum_{j=1}^{m}\left(y_{i j}-y_{0 j}\right)^{2}\right]^{\frac{1}{2}}, \quad i=1, \ldots, n$

$d_{0}=\bar{d}+2 S_{d}$,

$T M A I_{i}$ - taxonomic development measure for object $i$,

$d_{i}$ - distance of $i$ object from module,

$\bar{d}, S_{d}$ - mean and standard deviation $d_{i}$.

Market indicators and/or economic and financial ratios were selected for analysis as diagnostic variables, depending on the specific nature of the companies' operations (Nawrocki and Jabłoński, 2011; Tarczyński, 2013). The following indicators were taken into account for financial companies:

- profitability: return on assets (ROA), return on equity (ROE),

- capital adequacy (capital adequacy ratio),

- equity/total assets. 
On the other hand, for non-financial companies:

- liquidity ratios: current liquidity ratio, quick liquidity ratio,

- profitability ratios: asset profitability (ROA), return on equity (ROE), sales margin,

- debt ratios: total debt ratio,

- management efficiency: receivables turnover ratio, inventory rotation rate.

\section{The WAI measure}

Another synthetic measure that allows for the classification of companies is the investment attractiveness indicator (WAI) proposed by Lisek, Luty (2019). WAI is a simplified measure, which is less labour-intensive than the classic TMAI. Moreover, this measure isn't sensitive enough to the extreme and unusual elements (Lisek, Luty, 2019).

As with TMAI, to calculate WAI we create 2-dimensional data matrix containing observations $y_{i j}^{t}$ of the diagnostic features of selected objects in year $t$. We estimate the WAI as a weighted average:

$$
W A I_{i}=\sum_{t=1}^{s} w_{t} Q_{i}^{t}
$$

where:

$$
\begin{aligned}
w_{t} & =\frac{t}{1+2+\ldots+s}, \\
Q_{i}^{t} & =\frac{1}{m} \sum_{j=1}^{m} z_{i j}^{t},
\end{aligned}
$$

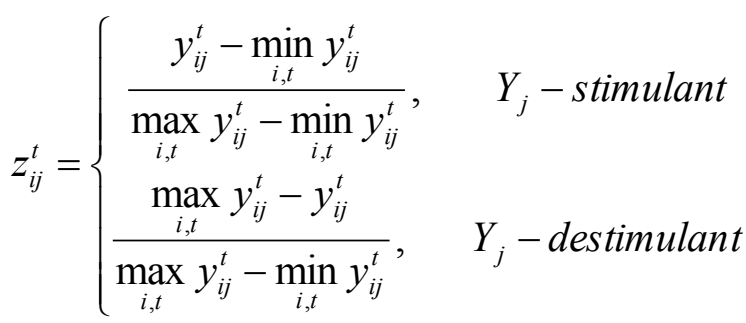

$W A I_{i}$ - value of investment attractiveness indicator for $i$-th object,

$Q_{i}^{t}$ - value of synthetic measure for $i$-th object in year $\mathrm{t}$,

$z_{i j}^{t}$ - value of $j$-th normalize diagnostic features for $i$-th object in year $\mathrm{t}$,

$w_{t}$ - the weight of a synthetic measure for $i$-th object in year $\mathrm{t}$,

$\mathrm{s}-$ number of periods. 
The following diagnostic variables have been used for the WAI structure for non-financial companies:

- liquidity ratios: current liquidity, quick liquidity,

- debt ratios: total debt, long-term debt,

- rotation rates: inventory turnover, receivables inflow, asset rotation,

- profitability ratios: profitability of sales, ROA, mortgage profit,

- market indicators: earnings per share, price - earnings ratio, price - book value, market value.

For financial companies the following were taken into account: total debt, receivables inflow, asset rotation, profitability of sales, ROA, mortgage profit, earnings per share, price earnings ratio, price - book value, market value.

\section{The Hurst Exponent}

The Hurst exponent (Hurst, 1951) is another measure that allows for the classification of time series, i.e. to distinguish chaotic time series generated by deterministic dynamic systems from the stochastic time series. The exponent has a value in the range $\langle 0,1\rangle$. If the time series is generated by a random walk (or a Brownian motion process) it has the value of $H=0.5$. If $0 \leqslant H<0.5$ the time series is antipersistent or ergodic. Such time series are characterized by the greatest probability of changes, because there are negative correlations between consecutive elements of the series. In the case of the stock market, the risk of a security is often equated with the volatility of a series of its prices or rates of return (Orzeszko, 2010). For a series for which $0.5<H \leqslant 1$, the series is persistent, i.e. reinforcing trend. They are characterized by the effect of a long memory, i.e. a large positive correlation between variables.

One of the methods of calculating the Hurst exponent is the method of the rescaled range $\mathrm{R} / \mathrm{S}$. For time series $\left\{x_{1}, x_{2}, \ldots, x_{N}\right\}$ it runs through the following steps (Chun, Kim, Kim, 2002):

Firstly, transform the above time series into $m=N-1$ logarithmic rates of return:

$$
y_{k}=\log \left(x_{k+1} / x_{k}\right), k=1,2, \ldots, N-1 \text {, }
$$

and divide the series (5) into $T$ parts made up of $t$ elements: $T=[\mathrm{m} / \mathrm{t}]$, where [ ] denotes the integer part of the argument. If the quotient $m / t$ is not an integer then $t T<m$ and we use values $y_{k}$ for $k=1,2, \ldots, t T$.

In the next step, define the:

$z_{i j}=y_{i j}-\bar{y}_{j}$, 
where: $y_{i j}$ is the $j$-th value in the $i$-th interval and $\bar{y}_{j}=\frac{1}{t} \sum_{i=1}^{t} y_{i j}$.

The range of the $i$-th interval is defined as:

$R_{j}=\max \left(q_{i j}\right)-\min \left(q_{i j}\right)$,

where: $q_{i j}=\sum_{l=1}^{i} z_{l j}, i=1,2, \ldots, t, j=1,2, \ldots, T$ is a sequence of partial sums $z_{l j}$ for each $i$.

Next, calculate the rescaled range series $(R / S)$ :

$(R / S)_{t}=(1 / T) \sum_{j=1}^{T} \alpha_{j t}$

$\alpha_{j t}=R_{j} / S_{j}$,

where: $S_{j}=\sqrt{\frac{1}{t} \sum_{i=1}^{t} z_{i j}^{2}}$.

The above procedure is carried out for different lengths of time series $t$. Finally, the value of the Hurst exponent is the slope of the graph of the logarithms $(R / S)_{t}$ to the axis of logarithms $t$.

\section{The division of companies}

In the study I used financial time series of the WIG30 index, which were listed on the Warsaw Stock Exchange for at least 8.5 years - from 2010 to 2018. Therefore, the following companies were taken into account: Asseco Poland SA (ACP), Grupa Azoty (ATT), CCC (CCC), CD Projekt (CDR), Cyfrowy Polsat (CPS), ENEA (ENA), Eurocash (EUR), ING Bank Śląski (ING), KGHM Polska Miedź (KGH), LPP (LPP), Lotos (LTS), mBank (MBK), Orange Poland (OPL), Bank Polska Kasa Opieki (PEO), Polska Grupa Energetyczna (PGE), Polskie Górnictwo Naftwe i Gazownictwo (PGN), PKN Orlen (PKN), Powszechna Kasa Oszczędności Bank Polski (PKO), Tauron (TPE).

At the beginning the beta coefficient was estimated for the above mentioned companies. These values were calculated on the basis of monthly rates of return in the period 1.1.201431.12.2018. Table 1 shows the value of the beta coefficient for the analysed companies. 
Table 1.

The beta coefficient for the analysed companies

\begin{tabular}{|c|c|c|c|c|c|}
\hline Series & Beta & $R^{2}$ & Series & Beta & $R^{2}$ \\
\hline ACP & 0.5239 & 0.1361 & LTS & 1.1510 & 0.2289 \\
\hline ATT & 0.7173 & 0.0713 & MBK & 1.3024 & 0.4046 \\
\hline CCC & 1.645 & 0.3673 & MIL & 1.2650 & 0.3558 \\
\hline CDR & 0.8692 & 0.0868 & OPL & 0.7738 & 0.1747 \\
\hline CPS & 0.3952 & 0.0972 & PEO & 0.7968 & 0.3178 \\
\hline ENA & 1.2873 & 0.2723 & PGE & 1.0246 & 0.2711 \\
\hline EUR & -0.0959 & 0.0014 & PGN & 1.0606 & 0.2851 \\
\hline ING & 1.0492 & 0.5071 & PKN & 1.4462 & 0.4243 \\
\hline KGH & 1.6111 & 0.3297 & PKO & 1.2531 & 0.5394 \\
\hline LPP & 1.4362 & 0.2311 & TPE & 1.0612 & 0.2528 \\
\hline
\end{tabular}

Based on the results presented in Table 1, it can be seen that not all beta values are statistically significant. Reliable results were obtained only for CCC, ING, KGH, MBL, MIL, PKN, PKO and PEO $\left(\mathrm{R}^{2}>0.3\right)$. The beta values obtained for these companies are greater than 1 , which means that investing in these shares is more risky than the market (WIG). An exception is PEO, for which beta $<1$. Therefore, investing in PEO is less risky than the WIG index.

In the next stage, the value of taxonomic measure TMAI and WAI was estimated on the basis of the algorithm described in points 2 and 3. In order to calculate TMAI I used data contained in financial reports of companies [11] for the third quarter of 2018, and for WAI for the third quarters in years 2014-2018 (Lisek, Luty) ${ }^{1}$. Table 2 shows the value of TMAI and WAI for the analysed companies.

Table 2.

The TMAI and WAI measures for the analysed companies

\begin{tabular}{|c|c|c|c|c|c|}
\hline Series & TMAI & WAI & Series & TMAI & WAI \\
\hline $\mathrm{ACP}$ & 0.1922 & 0.2032 & ING & 0.052572 & 0.6806 \\
\hline ATT & 0.0781 & 0.2221 & MBK & 0.275083 & 0.3308 \\
\hline $\mathrm{CCC}$ & 0.1541 & 0.3120 & MIL & 0.536546 & 0.3147 \\
\hline CDR & 0.4614 & 0.6087 & PEO & 0.356242 & 0.4393 \\
\hline CPS & 0.1823 & 0.2232 & $\mathrm{PKO}$ & 0.472839 & 0.4888 \\
\hline ENA & 0.1587 & 0.2282 & & & \\
\hline EUR & 0.1448 & 0.3422 & & & \\
\hline KGH & 0.2017 & 0.2137 & & & \\
\hline LPP & 0.2972 & 0.4523 & & & \\
\hline LTS & 0.2230 & 0.2964 & & & \\
\hline OPL & 0.0845 & 0.1674 & & & \\
\hline PGE & 0.1052 & 0.2089 & & & \\
\hline PGN & 0.2016 & 0.2691 & & & \\
\hline PKN & 0.2165 & 0.3263 & & & \\
\hline TPE & 0.0984 & 0.1978 & & & \\
\hline
\end{tabular}

Due to the value of the synthetic measure TMAI (or WAI) analysed non-financial companies were divided into four groups:

\footnotetext{
${ }^{1}$ The data come from the author's own calculations based on the financial reports of companies.
} 
- the company is very good: $T M A I_{i} \geq \overline{T M A I}+S_{T M A I},\left(W A I_{i} \geq \overline{W A I}+S_{W A I}\right)$,

- the good company: $\overline{T M A I}+S_{T M A I}>T M A I_{i} \geq \overline{T M A I},\left(\overline{W A I}+S_{W A I}>W A I_{i} \geq \overline{W A I}\right)$,

- the company is average: $\overline{T M A I}>T M A I_{i} \geq \overline{T M A I}-S_{T M A I},\left(\overline{W A I}>W A I_{i} \geq \overline{W A I}-S_{W A I}\right)$,

- the weak company: $\overline{T M A I}-S_{T M A I}>T M A I_{i},\left(\overline{W A I}-S_{W A I}>W A I_{i}\right)$,

where:

$\overline{T M A I}$ - average value of TMAI for the analysed companies,

$S_{T M A I}$ - standard deviation of TMAI for the analysed companies,

$\overline{W A I}$ - average value of WAI for the analysed companies,

$S_{W A I}$ - standard deviation of WAI for the analysed companies.

Table 3 presents the division of non-financial companies into four groups due to the values of TMAI and WAI.

Table 3.

The division of non-financial companies due to the values of TMAI and WAI

\begin{tabular}{|c|c|c|c|c|}
\hline & Very good company & Good company & Average company & Weak company \\
\hline TMAI & CDR, LPP & $\begin{array}{c}\text { ACP, KGH, LTS, } \\
\text { PGN, PKN }\end{array}$ & $\begin{array}{c}\text { CCC, CPS, ENA, EUR, } \\
\text { PGE, TPE }\end{array}$ & ATT, OPL \\
\hline WAI & CDR, LPP & $\begin{array}{c}\text { CCC, EUR, LTS, } \\
\text { PKN }\end{array}$ & $\begin{array}{c}\text { ACP, CPS, ENA, ATT, } \\
\text { KGH, PGE, PGN, TPE }\end{array}$ & OPL \\
\hline
\end{tabular}

Since the financial companies were only 5 , they were divided into two groups:

- the very good and good companies,

- the average and weak companies.

Table 4 presents the division of financial companies into two groups due to the values of TMAI and WAI.

Table 4.

The division of financial companies due to the values of TMAI and WAI

\begin{tabular}{|c|c|c|}
\hline Measure & Very good and good company & Average and weak company \\
\hline TMAI & MIL, PEO, PKO & ING, MBK \\
\hline WAI & ING, PKO & MBK, MIL, PEO \\
\hline
\end{tabular}

Analysing the data contained in Tables 2-4, it can be seen that the most attractive for the investor are the companies CDR, LPP and PKO for both taxonomic measures. The least attractive were OPL and MBK, which for the estimated measures occupied the last places in the ranking. In addition, half of the surveyed companies were assigned to the same groups, regardless of the measure used. Spearman's correlation coefficient for non-financial companies is 0.6429 , while for financial companies -0.7 . This means a moderate positive correlation between TMAI and WAI values for non-financial companies and a moderate negative correlation for financial companies. 
The Hurst exponent for the analysed companies was estimated on the basis of the algorithms described in point 3. For this purpose financial time series which were set up with logarithms of daily returns of closing price indexes of selected companies in period from 1.07.2010 to 31.12.2018 ${ }^{2}$ were used. Table 5 shows the value of Hurst exponent for the analysed companies.

Table 5.

The Hurst exponent for the analysed companies

\begin{tabular}{|c|c|c|c|}
\hline Series & Hurst exponent & Series & Hurst exponent \\
\hline ACP & 0.4832 & LPP & 0.5769 \\
\hline CCC & 0.5653 & MBK & 0.5164 \\
\hline CDR & 0.5701 & MIL & 0.5076 \\
\hline CPS & 0.4539 & OPL & 0.5365 \\
\hline ENA & 0.4972 & PEO & 0.4583 \\
\hline EUR & 0.5368 & PGE & 0.5295 \\
\hline ATT & 0.5791 & PGN & 0.4742 \\
\hline ING & 0.4837 & PKN & 0.5156 \\
\hline KGH & 0.5631 & PKO & 0.5129 \\
\hline LTS & 0.5567 & TPE & 0.5295 \\
\hline
\end{tabular}

The estimated values of the Hurst exponent for the analysed companies oscillate around the level of 0.5. 14 of them are persistent $(\mathrm{H}>0.5)$ i.e. strengthening the trend. While ACP, CPS, ENA, ING, PEO, PGN are slightly more risky.

\section{The investment portfolios}

Based on the above division of companies in the next stage of the research 8 portfolios with equal shares were constructed. Criteria for selection of companies to a portfolio and their share in investment portfolio are shown in Table 6. The value of the Hurst exponent allowed choosing the companies whose $H_{i}>0.5$ (portfolio 1) and those for which $H_{i}<0.5$ (portfolio 2). Due to the value of the TMAI measure companies were divided into two groups: very good and good companies (portfolio 3) and average and weak companies (portfolio 4). Similarly to TMAI, the value of the WAI indicator allowed choosing the companies that are very good and good (portfolio 5) and those that are average and weak (portfolio 6). In addition, based on the value of the beta coefficient companies were divided into two groups: $\beta>1$ (portfolio 7) and $0<\beta<1$ (portfolio 8).

\footnotetext{
${ }^{2}$ The data come from stooq.com, 1-30.06.2019.
} 
Table 6.

Criteria for selection and shares of companies in portfolios

\begin{tabular}{|c|c|c|c|c|}
\hline & Portfolio 1 & Portfolio 2 & Portfolio 3 & Portfolio 4 \\
\hline Criterion & Hurst $>0.5$ & Hurst $<0.5$ & $\begin{array}{c}\text { Very good and good } \\
\text { TMAI }\end{array}$ & $\begin{array}{c}\text { Average and weak } \\
\text { TMAI }\end{array}$ \\
\hline Companies & $\begin{array}{l}\text { ATT, CCC, CDR, } \\
\text { EUR, KGH, LPP, } \\
\text { LTS, MBK, MIL, } \\
\text { OPL, PGE, PKN, } \\
\quad \text { PKO, TPE }\end{array}$ & $\begin{array}{l}\text { ACP, CPS, ENA, } \\
\text { ING PEO, PGN }\end{array}$ & $\begin{array}{l}\text { ACP, CDR, KGH, } \\
\text { LPP, LTS, MIL, } \\
\text { PEO, PGN, PKN, } \\
\text { PKO }\end{array}$ & $\begin{array}{c}\text { ATT, CCC, CPS, } \\
\text { ENA, EUR, ING, } \\
\text { MBK, OPL, PGE, } \\
\text { TPE }\end{array}$ \\
\hline $\begin{array}{l}\text { Share of } \\
\text { portfolio }\end{array}$ & 0.0714 & 0.1667 & 0.100 & 0.100 \\
\hline & Portfolio 5 & Portfolio 6 & Portfolio 7 & Portfolio 8 \\
\hline Criterion & $\begin{array}{c}\text { Very good and good } \\
\text { WAI }\end{array}$ & $\begin{array}{c}\text { Average and weak } \\
\text { WAI }\end{array}$ & BETA $>1$ & BETA $<1$ \\
\hline Companies & $\begin{array}{c}\text { CCC, CDR, EUR, } \\
\text { ING, LPP, LTS, } \\
\text { PKN, PKO }\end{array}$ & $\begin{array}{l}\text { ACP, ATT, CPS, } \\
\text { ENA, KGH, MBK, } \\
\text { MIL, OPL, PEO, } \\
\text { PGE, PGN, TPE }\end{array}$ & $\begin{array}{l}\text { CCC, ENA, ING, } \\
\text { KGH, LPP, LTS, } \\
\text { MBK, MIL, PGE, } \\
\text { PGN, PKN, PKO, } \\
\text { TPE }\end{array}$ & $\begin{array}{l}\text { ACP, ATT, CDR, } \\
\text { CPS, EUR, OPL, } \\
\text { PEO }\end{array}$ \\
\hline $\begin{array}{l}\text { Share of } \\
\text { portfolio }\end{array}$ & 0.1250 & 0.0833 & 0.0769 & 0.1429 \\
\hline
\end{tabular}

Table 7 shows the value of the expected rate of return, risk and annual rate of return of constructed portfolios. The annual rate of return was estimated based on the closing prices of the shares of the companies included in the portfolio from 28.12.2018 and 28.10.2019.

Table 7.

The expected rate of return, risk and annual rate of return for portfolios

\begin{tabular}{|c|c|c|c|c|}
\hline & $\begin{array}{c}\text { expected } \\
\text { rate of return }\end{array}$ & variance & risk & $\begin{array}{c}\text { annual } \\
\text { rate of return }\end{array}$ \\
\hline Portfolio 1 & -0.000602 & 0.000192 & 0.013863 & 0.101635 \\
\hline Portfolio 2 & -0.000001 & 0.000097 & 0.009871 & 0.120043 \\
\hline Portfolio 3 & 0.000446 & 0.000140 & 0.011819 & 0.024446 \\
\hline Portfolio 4 & -0.001289 & 0.000214 & 0.014633 & 0.337760 \\
\hline Portfolio 5 & -0.000401 & 0.000226 & 0.015022 & -0.010400 \\
\hline Portfolio 6 & -0.000435 & 0.000125 & 0.011159 & 0.168637 \\
\hline Portfolio 7 & -0.000467 & 0.000180 & 0.013427 & 0.019331 \\
\hline Portfolio 8 & -0.000337 & 0.000149 & 0.012216 & 0.387427 \\
\hline
\end{tabular}

Based on the data contained in Table 6 , it can be seen that only portfolio 3 built from the best companies according to the TMAI ranking is characterized by a positive expected rate of return and at the same time one of the lowest risk levels. The actual half-year rate of return for this portfolio turned out to be one of the lowest and amounted to $2.4 \%$. The highest real halfyear rate of return was obtained for portfolio 8 , created from defensive companies $(0<\beta<1)$, then for portfolio 4 built from the weakest companies in the TMAI ranking. The worst in this ranking was the portfolio 5, for which the actual rate of return is negative and at the same time the level of risk is the highest. The lowest risk level is represented by portfolio 2 , built on the basis of companies for which $H_{i}<0.5$. 


\section{Conclusion}

The above-mentioned measures allowed to rank and divide listed companies into more and less attractive ones for the investor. The conducted research shows that, taking into account the fundamental approach, better results were obtained for portfolios built on the basis of the TMAI measure rather than WAI. The use of nonlinear dynamic systems tools such as the Hurst exponent seems to be an important element of portfolio analysis research. The conducted research has shown that the selection of shares to the portfolio based on the Hurst exponent often gives better or just as good results as the fundamental methods that take into account the company's economic and financial situation.

\section{References}

1. Chun, S.H., Kim, K.J., Kim, S.H. (2002). Chaotic analysis of predictability versus knowledge discovery techniques: case study of the Polish stock market. Expert Systems, Vol. 19, No. 5, 264-272.

2. Hurst, H.E. (1951). Long term storage capacity of reservoirs. Trans. Am. Soc. Eng. 116, 770-799.

3. Jajuga, K., Jajuga, T. (2000). Inwestycje, instrumenty finansowe, ryzyko finansowe, inżynieria finansowa. Warszawa: PWN.

4. Lisek, S., Luty, L. (2019). Propozycja wskaźnika atrakcyjności inwestycyjnej przedsiębiorstwa. Wiadomości Statystyczne. The Polish Statistican, vol 64(4), 49-67.

5. Nawrocki, T., Jabłoński, B. (2011). Inwestowanie na Rynku Akcji. Jak Ocenić Potencjat Rozwojowy Firm Notowanych na GPWw Warszawie. Wydawnictwo CeDeWu.

6. Tarczyński, W. (1994). A taxonomic measure of the attractiveness of investments in securities. Przeglad Statystyczny, No. 3, 275-300.

7. Tarczyński, W. (2002). Fundamentalny portfel papierów wartościowych. Warszawa: PWE.

8. Tarczyński, W. (2013). Ocena efektywności metod analizy portfelowej na Giełdzie Papierów Wartościowych w Warszawie za lata 2001-2013. Zeszyty Naukowe Uniwersytetu Szczecińskiego, nr 761, Finanse, Rynki Finansowe, Ubezpieczenia, nr 60. Szczecin, 537-550.

9. Tarczyński, W. (1999). The fundamental attitude to building a stock portfolio. Argumenta Oeconomica, No. 1(7). Wrocław, 153-168.

10. Tarczyński, W., Łuniewska, M. (2004). Portfele klasyczne, fundamentalne i zdywersyfikowane poziomo - analiza porównawcza. Acta Universitatis Lodziensis, Folia Oeconomica, 177, 171-189. 